\title{
Factors affecting plasma chemistry values of the Spanish Imperial Eagle, Aquila adalberti ${ }^{1}$
}

\author{
Miguel Ferrer *, Pablo Dobado-Berrios \\ Estación Biológica de Doñana, Consejo Superior de Investigaciones Científicas, Avd. María Luisa, Pabellón del Perú, E-41013 Sevilla, Spain
}

\begin{abstract}
Studies in endangered raptors have given reference values for some blood constituents of metabolic, veterinary, ecological and/or taxonomic interest. However, the variations in such values with physiological and external factors are poorly known. In the present study, the influence of sex, age, nutritional state and local environment was tested on up to 19 plasma variables in the Spanish Imperial Eagle (Aquila adalberti). Our results showed that differences between sexes were not significant for any of the studied parameters. However, age had a significant effect on a number of metabolites, inorganic ions and enzyme activities. In particular, age-related differences in glucose, triglyceride, lactate dehydrogenase, creatine phosphokinase and creatinine values between chick and (sub)adult eagles were found. In addition, some metabolic responses of subadult birds to fasting and refeeding were quite similar to those found in other raptors. Finally, nestlings inhabiting different geographic areas also differed in relation to the values of several plasma parameters, those dissimilarities probably accounting for quantitative and qualitative differences in their respective diets. (C) 1998 Elsevier Science Inc. All rights reserved.
\end{abstract}

Keywords: Age; Aquila adalberti; Blood chemistry; Local environment; Nutritional state; Sex; Spanish Imperial Eagle

\section{Introduction}

An adequate knowledge of blood chemistry is greatly recommended for those projects involving research and management of populations of vulnerable species [7]. Related studies on birds of prey have provided some basic data of metabolic, veterinary, ecological and/or taxonomic interest $[3,22,43]$. However, most of those studies were undertaken in homogeneous groups of specimens, or else the low available amount of those wild birds forced researchers to group rather different individuals together. Therefore, the variability in plasma values and their reliance on intraspecific factors are far from being well documented.

\footnotetext{
* Corresponding author. Tel.: + 3495 4232340; fax: + 3495 4621125 .

${ }^{1}$ Communicated by $\operatorname{Dr}$ M. Thorndyke, Editorial Board.
}

Available information indicates that the values of some blood parameters can vary according to the nutritional state $[15,16,32,35,53]$ and/or the circadian rhythm [17]. Changes in the activity of some plasma enzymes as a result of the exposure of birds of prey to environmental toxicants have been also reported [24]. The influence of other factors such as sex, age and local environment cannot be ruled out, but references to them in the literature are scarcely sufficient for raptors $[19,42,55]$. Hence, it would be desirable to determine specific values of blood chemicals by analyzing separately specimens under different physiological or external states. Reference data so obtained could be used in a wide range of conditions.

In this paper we report on 19 plasma parameters (including metabolites, total protein, inorganic ions and enzyme activities) from up to 81 Spanish Imperial Eagles. That is one of the seven most endangered 
raptorial species in the world [26]. Nowadays fewer than 150 pairs exist [13]. The main objective of our study was to determine whether their plasma values varied depending on sex, age and nutritional state. In addition, differences between two groups of free-living birds inhabiting different geographic areas were considered.

\section{Material and methods}

\subsection{Animals}

From 1986 to 1989 a total of 52 nestling (34-75-dayold, mean body weight $=2650 \mathrm{~g}$, weight range $=1800-$ $3700 \mathrm{~g}), 12$ subadult (90-day- to 4-year-old, mean body weight $=3870 \mathrm{~g}$, weight range $=2700-4700 \mathrm{~g}$ ), and ten adult (5-18-year-old, mean body weight $=3930 \mathrm{~g}$, weight range $=2900-4800 \mathrm{~g})$ Spanish Imperial Eagles was bled to achieve separate reference data.

The exact ages (days) were previously known in all birds. The age of nestlings was determined by previous checks of the nests, and all adults and subadults were previously banded as nestlings in their nests. All nestlings lived in the wild, 41 animals belonging to a population in southwestern Spain (Doñana National Park, approx. $37^{\circ} \mathrm{N}, 6^{\circ} 5^{\prime} \mathrm{W}$ ), and 11 animals to one in central Spain near Madrid (approx. 40 $29^{\prime} \mathrm{N}, 4^{\circ} 28^{\prime}$ $\mathrm{W})$. Those groups, whose mean ages were not statistically different ( $51 \pm 1$ and $55 \pm 3$ day-old, respectively), will be referred to as a population of Doñana and a population of Madrid. On the other hand, subadult and adult eagles belonged to the Raptor Recuperation Centers of Doñana Biological Station (Matalascañas, Spain) and ICONA Territorial Section (Sevilleja de la Jara, Spain). Those were examined macroscopically and radiographed there, and birds with clinical signs of disease or traumatic injuries which could affect the data substantially were discarded. Therefore, only healthy subadults and adults were confined in specially designed pens at air temperature and natural photoperiod, and fed ad libitum freshly whole rabbit and chicken carcasses (approx. 17.4\% protein, 24.8\% fat, $0.9 \%$ ash and $56.9 \%$ moisture; for both food types [56]).

Sex distinction was made through a discriminate analysis based on the measurements of tarsus and forearm [14]. Thus, the chick group consisted of 23 males and 29 females (being 18 males and 23 females from the population of Doñana, and five males and six females from that of Madrid), the subadult group consisted of seven males and five females, and the adult group consisted of four males and six females. The differences in the mean age (days) between sexes were not statistically significant for any of the studied age groups.

\subsection{Blood collecting procedures}

Up to 2-ml samples of blood were taken with a heparinized syringe from the brachial vein, which was massaged carefully after bleeding to prevent the occurrence of hematomas. All samples were collected between 11:00 and 15:00 to minimize any variation in blood chemicals caused by the circadian rhythm $[12,17]$. Blood was carefully placed into tubes containing lithium heparin to prevent coagulation, and avoiding formation of bubbles. The blood collection tubes were kept on ice $\left(4^{\circ} \mathrm{C}\right)$ in cool containers to avoid denaturation of proteins, and carried to the laboratory (Valme Hospital, Sevilla, Spain) within $8 \mathrm{~h}$ after blood withdrawal. Then, each blood sample was centrifuged at $3000 \mathrm{rpm}$ for $10 \mathrm{~min}$ and plasma stored at $-60^{\circ} \mathrm{C}$ until analysis.

\subsection{Tested parameters}

Biochemical analyses were performed on a computer process-controled multichannel autoanalyser (Hitachi 747; Tokyo, Japan) by using commercial kits (Boehringer-Mannheim Biochemica; Mannheim, Germany). The following 19 determinations were made in each plasma sample (the abbreviations and methods indicated in parentheses): glucose (GOD-PAP method), urea (urease method), uric acid (uricase method), cholesterol (CHOH-PAP method), triglycerides (enzymatic method), bilirubin (DPD method), creatinine (kinetic Jaffé reaction), total protein (biuret reaction), calcium (cresolphtalein complexone reaction), sodium (ion-selective-electrode), potassium (ion-selective-electrode), glutamic oxaloacetic transaminase (GOT; I.F.C.C. technique), glutamic pyruvate transaminase (GPT; I.F.C.C. technique), creatine phosphokinase (CPK; UV NAC activated), lactate dehydrogenase (LDH; UV), cholinesterase (butiryl-thiocholin reaction), aldolase (UV enzymatic method), gamma-glutamyl transpeptidase (-GT; L-gamma-glutamylp-nitroanalide), and amylase (maltotetraose reaction).

In order to assess whether the plasma levels of glucose, urea, uric acid, cholesterol and/or triglycerides varied depending on the nutritional state, seven additional non-diseased subadult eagles (i.e. four males and three females) were bled twice each: first, on admission into the Doñana Raptor Recuperation Center, the birds on account of non-traumatic flightless and low weight, and second, after a subsequent 3-week refeeding in captivity as described above.

\subsection{Statistical analyses}

All data are expressed as mean \pm standard error (S.E.), and ranges are also provided. The statistical 


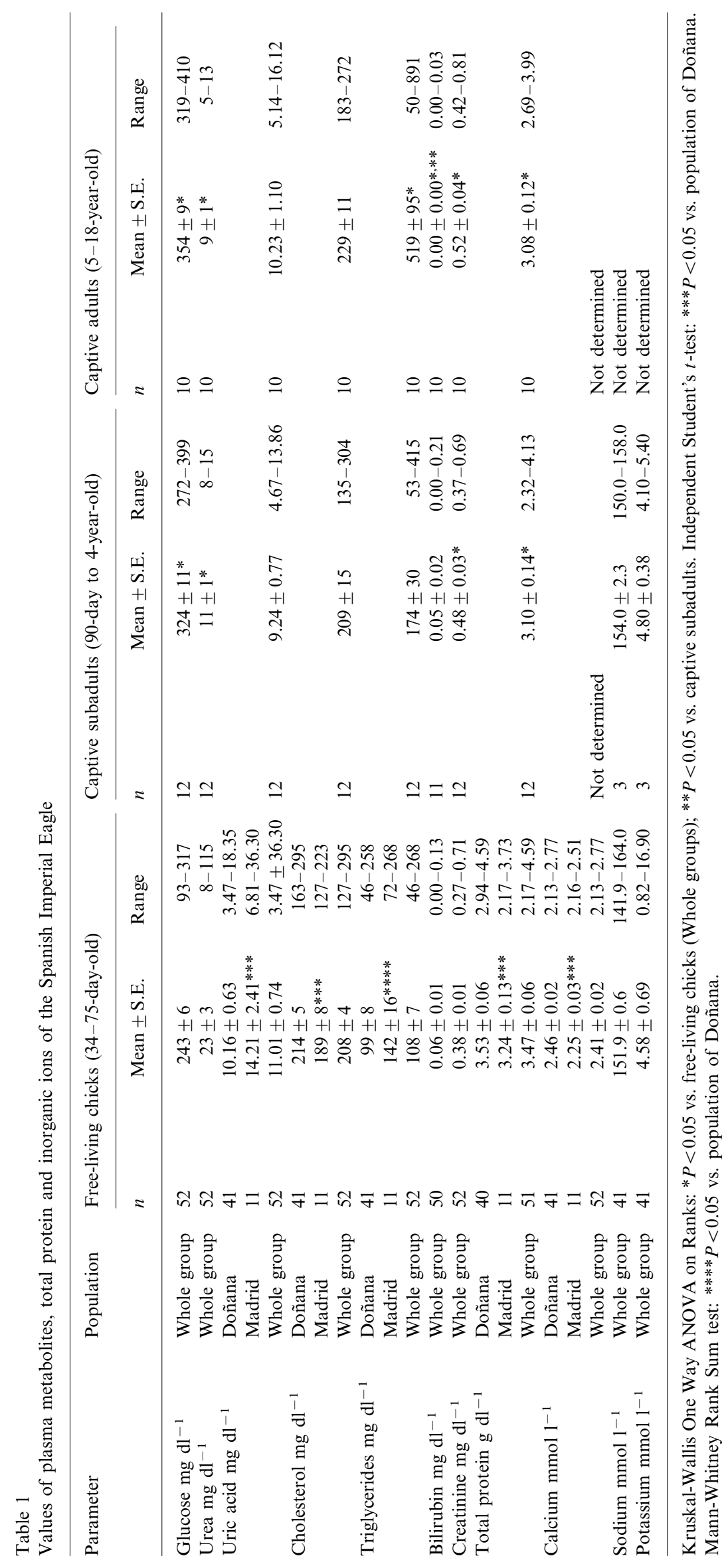


analyses were carried out with the software packages SIGMASTAT 1.02 (Jandel Scientific; Corte Madera, CA) and STATGRAPHICS 6.0 (Statistical Graphics Corporation; Rockville, MD). Differences were considered significant at $P<0.05$. Before comparing two independent groups, the data were tested for normality using the Kolmogorov-Smirnov test (with Lilliefors' correction), and for equal variance using the Levene Median test. If the data groups passed both tests, the comparison was made by the parametric independent Student's $t$-test. If the normality and/or equal variance test was violated, the comparison was made by the non-parametric Mann-Whitney Rank Sum test. An identical criterion was established for analyzing the values of plasma metabolites in subadult eagles under natural starvation and after subsequent refeeding, but the parametric paired Student's $t$-test or the non-parametric Wilcoxon Signed Rank test were used in those cases. The non-parametric Kruskal-Wallis One-Way Analysis of Variance (ANOVA) on Ranks and subsequent Multiple Comparison (Dunn's method) were used to compare many data groups, since assumptions for parametric tests were always violated. The parametric Pearson Product-Moment Correlation was used to examine the linear concomitant variation of age and plasma values if those met normality and homoscedacity (constant variance) criteria. If those did not, the non-parametric Spearman Rank Order Correlation was used.

\section{Results}

No differences between sexes were found for any of the plasma variables. Therefore, data summarized in Table 1 (plasmatic metabolites, total protein and inor-

Table 2

Plasma enzyme activities $\left(\mathrm{U}^{-1}\right)$ of the Spanish Imperial Eagle

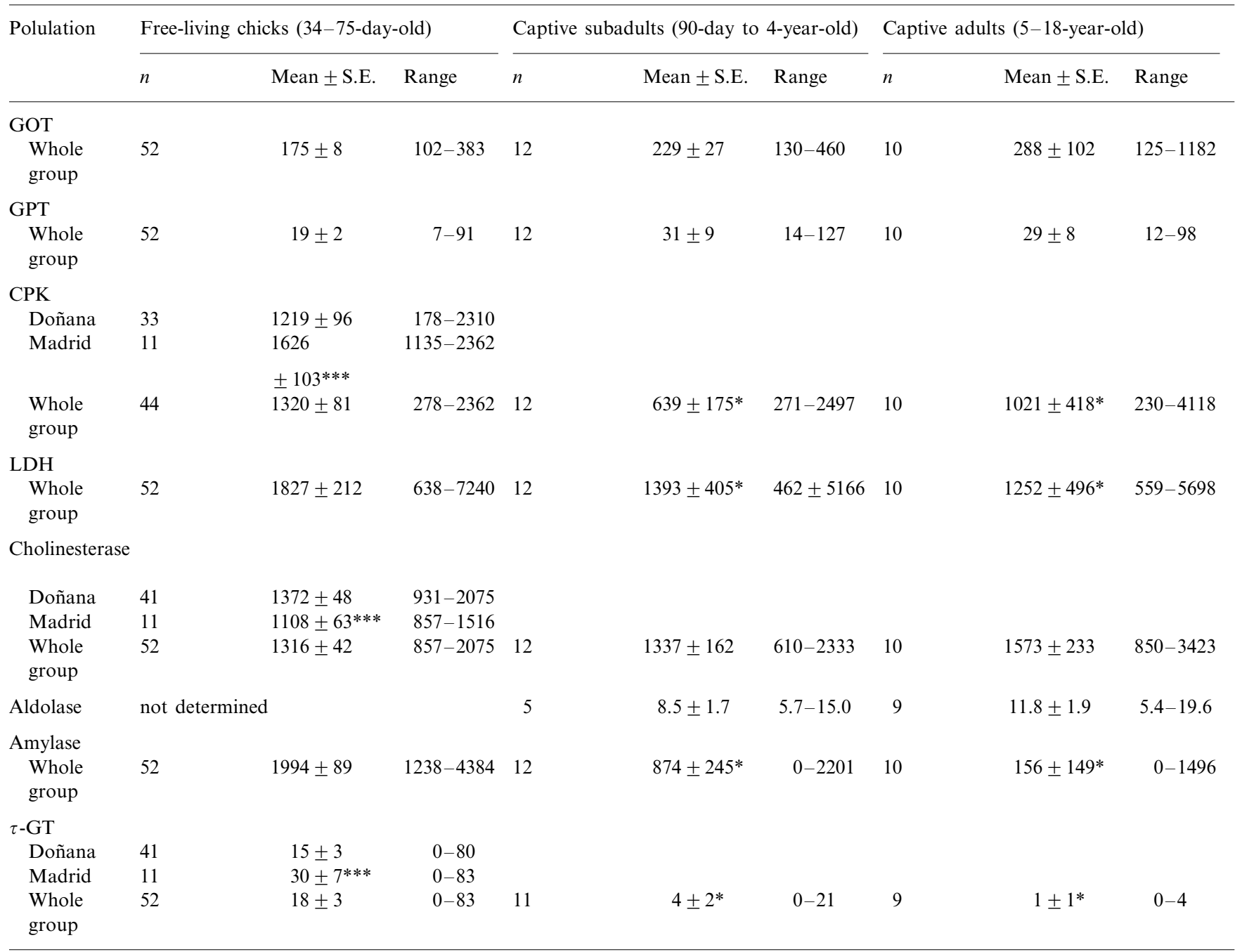

Kruskal-Wallis One Way ANOVA on Ranks: $* P<0.05$ vs. free-living chicks (whole groups). Independent Student's $t$-test: $* * * P<0.05$ vs. population of Doñana. 
Table 3

Linear correlations between age and plasma parameters of the Spanish Imperial Eagle

\begin{tabular}{|c|c|c|c|c|c|}
\hline Parameter & $n$ & Correlation & Coefficient $^{\mathrm{a}}$ & $P$-value & Tendency with age \\
\hline Glucose & 74 & SROC & 0.489 & $<0.005$ & + \\
\hline Urea & 74 & SROC & -0.502 & $<0.005$ & - \\
\hline Cholesterol & 74 & PPMC & 0.163 & 0.165 & $=$ \\
\hline Triglycerides & 74 & SROC & 0.490 & $<0.005$ & + \\
\hline Bilirubin & 71 & PPMC & -0.453 & $<0.001$ & - \\
\hline Sodium & 46 & SROC & 0.354 & 0.016 & + \\
\hline Potassium & 46 & SROC & 0.184 & 0.219 & $=$ \\
\hline GOT & 74 & SROC & 0.056 & 0.637 & $=$ \\
\hline GPT & 74 & SROC & 0.133 & 0.257 & $=$ \\
\hline CPK & 66 & SROC & -0.339 & 0.006 & - \\
\hline $\mathrm{LDH}$ & 74 & SROC & -0.417 & $<0.005$ & - \\
\hline
\end{tabular}

${ }^{a}$ SROC, Spearman Rank Order Correlation; PPMC, Pearson Product-Moment Correlation.

$\mathrm{b}+$, increasing plasma values; - decreasing plasma values; $=$, no change.

ganic ions) and Table 2 (plasma enzyme activities) correspond to males and females grouped together. A few chemicals were not analyzed in all age groups, because of the impossibility of obtaining more samples. On the other hand, some plasma values varied in nestlings inhabiting different places. Only those being statistically different are given in tables.

Significant changes in the mean values of many plasma parameters were observed between age groups. However, those differences could result, at least partially, from the different nutritional state of the animals, since comparisons involved free-living chicks and captive subadults and adults fed ad libitum. Likewise, variations in the values of other blood components with age might have passed unnoticed. To isolate which parameters underwent real age-related changes, the linear correlation between their values in the blood plasma and the exact age (days) was examined (Table 3 ). Glucose, triglyceride, creatinine and sodium values tended to increase significantly as the age advanced. Urea, bilirubin, total protein, CPK, LDH, amylase and - GT values decreased with advancing age, and there was no detectable relationship between age and the values of uric acid, cholesterol, potassium, GOT, GPT, cholinesterase or aldolase.

Finally, Table 4 shows the mean concentration of some plasma metabolites in subadult eagles suffering from undernourishment on arrival at the Doñana Raptor Recuperation Center. The corresponding levels after being adequately refed are also given. According to our preliminary analysis, males and females were grouped together. The concentrations of urea and uric acid were significantly higher, but cholesterol levels were signifi- cantly lower on admission. Plasma glucose increased and triglyceride levels decreased once birds were fed well in captivity, but those changes were not statistically significant.

\section{Discussion}

The main objective of this study was to determine whether plasma values of the Spanish Imperial Eagle were under the influence of sex, age, nutritional state and locality. We used relatively high sample sizes for wild bird species to good purpose. A preliminary analysis showed no differences between sexes for any of the

\section{Table 4}

Values of some plasma metabolites of subadult Spanich Imperial Eagles $(n=7)$ in undernourished conditions on arrival at a recuperation center and after a subsequent refeeding period in captivity

\begin{tabular}{|c|c|c|c|c|}
\hline \multirow{2}{*}{$\begin{array}{l}\text { Parameter } \\
\left(\mathrm{mg} \mathrm{dl}^{-1}\right)\end{array}$} & \multicolumn{2}{|c|}{ On admission } & \multicolumn{2}{|c|}{ After 3-week refeeding } \\
\hline & $\begin{array}{l}\text { Mean } \\
\pm \text { S.E. }\end{array}$ & Range & $\begin{array}{l}\text { Mean } \\
\pm \text { S.E. }\end{array}$ & Range \\
\hline Glucose & $298 \pm 23$ & $231-376$ & $325 \pm 22$ & $262-410$ \\
\hline Urea & $36 \pm 10$ & $18-89$ & $9 \pm 1 * *$ & $8-11$ \\
\hline Uric acid & $\begin{array}{l}11.16 \\
\pm 1.22\end{array}$ & $6.72-14.77$ & $\begin{array}{l}6.23 \\
\pm 0.79 *\end{array}$ & $4.26-10.56$ \\
\hline Cholesterol & $204 \pm 17$ & $148-281$ & $239 \pm 18^{* *}$ & $174-304$ \\
\hline $\begin{array}{l}\text { Triglyce- } \\
\text { rides }\end{array}$ & $95 \pm 18$ & $54-181$ & $74 \pm 16$ & $50-167$ \\
\hline
\end{tabular}

$P<0.05$ versus values on admission: * paired Student's $t$-test; ** Wilcoxon signed rank test. 
studied constituents. Both our present and other previous results $[4,29,34,37,39,42,47,50-52,54]$ support that sex-related values in most bird species are exhibited in hematocytological parameters (e.g. red cell number, hematocrit, cell hemoglobin, etc.) rather than in plasma variables. Notwithstanding, sexual differences concerning values of certain metabolites and/or enzyme activities have been described for some species of anseriforms [11,36] and ciconiforms [42].

\subsection{Comparative plasma chemistry}

Measurements of most plasma parameters in captive subadult and adult Spanish Imperial Eagles were quite similar to those previously obtained from captive sub(adult) birds of the same species $[42,43]$, but comparatively high potassium levels were found in our study. No values have been previously reported for the corresponding chicks. Our results indicated a high overlap between ranges of plasma values of free-living nestling Spanish Imperial Eagles and those of chicks of other raptorial species, including captive American Kestrels (Falco sparverius) [24], free-living Bald Eagles (Haliaeetus leucocephalus) [49] and kites (Milvus milvus and $M$. migrans) [5,55]. Close similarities were also found with free-living nestling storks (Ciconia ciconia and C. nigra) [48], and farmed chick Emus (Dromaius novaehollandiae) [8], but not with free-living chick Greater Flamingos (Phoenicopterus ruber) [46].

We have also provided herein reference data of some plasma chemicals which are insufficiently known for raptors and birds in general. Briefly, Spanish Imperial Eagles appeared to exhibit low bilirubin and cholinesterase, similar amylase, and high aldolase values compared to those given for the few avian species in which those parameters have been measured $[1,10,17,18,39,46,49]$.

\subsection{Age-related changes}

Age had a significant effect on a number of blood plasma constituents of the Spanish Imperial Eagle. This is in agreement with the findings of other authors [45] in wintering Common Cranes (Grus grus) [45], in farmed Emus [8], and in free-living White Spoonbills (Platalea leucorodia) [9]. A few age-related changes have been also published for other wild bird species, e.g. captive and free-living Canvasback Ducks (Aythya valisineria) [27,40], Mallard (Anas platyrhynchos) [11], free-living White Storks [2], and zoo Greater Flamingos [46]. We cannot draw any conclusion on age differences from a study which showed some reference data for free-living chick and captive adult Bald Eagles [49]. Since those age-grouped birds could also differ in their nutritional state, a mere comparison of their mean values should be unreliable unless the changes were assessed by linear correlations.
Both triglyceride and glucose concentration increased significantly with age in the Spanish Imperial Eagles. Also, ducks [40] and storks [2], but not cranes [45], showed the age-related change in triglyceride levels. Mean plasma glucose values in the nestling eagles were slightly higher than those reported for chick Marsh Harriers (Circus aeruginosus) [19]. Those authors found that glucose concentration was lower in males $(0.5-0.6$ $\mathrm{kg}$ body weight) than in females $(0.7-0.8 \mathrm{~kg}$ body weight), but that dissimilarity was caused by weight rather than by sex differences themselves.

More recently, it has been demonstrated that also triglyceride levels were comparatively high in those zoo bird species with a high body weight [42]. Consequently, the age-related increasing values of glucose and triglycerides in the eagle plasma might have been reflections of an increase in body weight. In relative terms, metabolic rate can decrease as Spanish Imperial Eagles [20] and birds in general grow [21], and may result in a reduced intake of glucose and triglycerides from the blood. Regarding the sugar, the hypothesis may be clarified by the measurements of LDH activities in the eagle plasma. Since those values decreased significantly with age, a diminished glycolytic rate in tissues might be suggested as partial responsible for a reduced glucose clearance. Also chickens [34] and Mallards [11] exhibited an age-related decrease in LDH activity. Moreover, 5-month-old flamingos showed low glucose concentrations and high $\mathrm{LDH}$ values compared with adults aged between 3 and 6 years [46]. These age-related changes (as those in triglyceride concentrations) were not statistically significant in the latter study, possibly because of the weight of the specimens compared was not too different.

Mean urea level in the nestling eagles was double that of uric acid. However, the values for urea decreased with age whereas those for uric acid remained unchanged, resulting in similar concentrations of both aminic nitrogenous waste materials in subadults and adults. Those observations seem to indicate that the relative contribution of urea to the total nitrogen excretion becomes smaller when young eagles leave the nest. Since the water volume required for excreting urea in the urine is much larger than that needed to eliminate uric acid [28], the physiological change that we report herein could account for reasons of weight economy related to flight activity.

Cholesterol levels in the eagles were not affected by age. Similar findings were reported in studies in which the youngest specimens were over 1-month-old [44-46]. However, adult Emus showed lower cholesterol values than 1-week-old chicks, these being attributed to a high dietary fat from the yolk sac of those precocial birds [8].

CPK catalyzes the conversion of ATP and creatine to phosphorylated creatine, which is an important storage 
form of high-energy phosphate in muscular tissue of many vertebrates [28]. Plasma CPK activities in subadult and adult eagles were significantly lower than in the nestlings. Emus also showed a comparable agerelated decrease in CPK values [8]. In addition, positive correlations between plasma CPK and LDH activities have been found in a number of zoo pelecaniform, ciconiform, falconiform and columbiform species [42]. Therefore, an increased weight might explain the agerelated decrease of CPK values in the eagle plasma. For example, the phosphocreatine/creatine ratio in muscle might be reduced as the birds grow and their relative metabolic rates decrease. The higher plasma creatinine content of subadult and adult eagles agrees with that, since this non-protein nitrogen compound is the end product of the creatine catabolism [28]. In chickens, a positive concomitant variation of creatinine concentration and body weight has been described [4]. In adult Night Herons (Nycticorax nycticorax) and Little Egrets (Egretta garzetta), CPK activities tended to be lower and creatinine levels tended to be higher than in the corresponding young [44]. According to those data, increasing values of plasma creatinine with age might point to increasing concentrations of phosphate-free creatine in muscle, because of the decline of CPK activity as the relative metabolic rate decreases.

Bilirubin, total protein and sodium levels, as well as amylase and - GT values differed also across the age profiles sampled, but we have not been able to find any metabolic or physiological explanation for those changes.

\subsection{Reliance on nutritional state}

The subadult eagles under natural starvation (Table 4) had lower plasma glucose than the captive normal birds fed ad libitum (Table 1). Related studies have shown that, after a period of experimental fasting, glucose levels remained steady in Black Vultures (Coragyps atratus) [35] and Herring Gulls (Larus argentatus) [25], or even increased in Common Buzzards (Buteo buteo) [16]. Such differences could indicate different abilities among wild bird species to survive under conditions of food deprivation. As we have previously suggested [15], a different effectiveness of the gluconeogenetic pathway could underlie those abilities.

Some authors considered that high levels of uric acid and/or urea in the plasma of the birds-of-prey result only from ingesting large quantities of animal protein, the main component of the diet [31,42]. Nevertheless, eagles suffering from malnutrition also showed relatively high levels of uric acid and markedly high urea concentrations. We have reported similar observations in undernourished Eagle Owls (Bubo bubo), Griffon Vultures (Gyps fulvus) and Red Kites (Milvus migrans) on admission into recuperation centers [15], as well as in experimentally fasted buzzards [16]. According to other authors [30,38], those high levels may be attributed to an increased self-catabolism of tissue proteins as an energy source and enhanced excretion of nitrogenous components throughout the fasting period, since levels of uric acid and urea fell even below the baseline after subsequent refeeding a diet containing $17.4 \%$ protein [56].

Unlike the above mentioned raptorial species, starvation did not appear to affect cholesterol concentrations in the eagles. Nevertheless, those levels increased when birds were adequately refed, as also it did in owls, vultures and kites [15], but not in buzzards [16]. Since cholesterol is a usual component of the blood lipoproteins, its concentration might be increased by feeding a high protein diet [41]. However, early studies in chickens documented that the serum cholesterol was inversely related to the dietary protein level [57]. Therefore, the hypercholeresterolemia found in most undernourished raptors after refeeding may be merely caused by the increased lipid ingestion and absorption, and subsequent cholesterol synthesis, after feeding supplies also containing $28.4 \%$ fat.

Previous studies did not report on triglyceride response of birds of prey to fasting and refeeding. These values were low in the undernourished eagles in comparison to those in the reference birds fed ad libitum. In gulls, a period of experimental starvation had no effect on triglyceride concentrations [25]. However, triglyceride concentration in the eagle plasma remained still far from reaching the normal values once the refeeding phase concluded. That inconsistent response appears to question the suitability of the triglyceride test to ascertain if wild birds are quantitatively well fed or not. In agreement with that, it is known that triglyceride levels differed widely among farmed young Ostriches (Struthio camelus), despite that all specimens sampled were in healthy conditions and were fed the same diet [29].

\subsection{Differences between local populations}

A comparison of plasma values in two groups of free-living chick eagles, belonging, respectively to the populations of Doñana and Madrid, was carried out to investigate the presumptive effect(s) of a different local environment. Biochemical analyses showed that nestlings differed in their plasma CPK, cholinesterase and -GT values. Abnormal changes in the activity of two former enzymes have been noted in rats [6], quail [10] and/or nestling kestrels [24] fed experimental diets containing non-lethal levels of pesticides or heavy metals. Thus, the different CPK and cholinesterase activities in chick eagles of Doñana and Madrid might be also explained by a differential ingestion of environmental toxicants in food material. In fact, differences in 
the concentration of some organochlorines (e.g. $\mathrm{HCH}$ and PCBs) and heavy metals (e.g. mercury, copper and zinc) in eggs of free-living Spanish Imperial Eagles from different geographic areas have been reported [23].

Unlike enzymes in the kestrel plasma, metabolites and total protein were not affected by lead treatment [24]. Interestingly, our results showed that nestlings of Doñana and Madrid also differed about the values of some metabolites, including cholesterol and triglycerides. In birds, both blood constituents are affected by the qualitative composition of the diet [30,42,57]. In this respect, it might be important the different frequencies of waterfowl (e.g. ducks, geese and coots) in the diet of the populations of Spanish Imperial Eagles during the breeding season, those accounting for $19.6 \%$ of total prey in Doñana, and for $0.4 \%$ in the central Spain [20]. However, it is difficult to determine whether those diets, despite their varying fat content, influenced somewhat the cholesterol and/or triglycerides values of chicks from different populations. Differences in plasma total protein were also observed, the mean levels being significantly higher in the nestlings of Donana than in those of Madrid. Furthermore, a concomitant dissimilarity in calcium concentrations matched the difference in protein values, a direct relationship which was described for parrots [31] and captive adult Peregrine Falcons (F. peregrinus) [33]. Total protein estimation is a useful test for evaluating the general nutritional state of birds of prey, the extremely low values being indicative of malnutrition [53]. Thus, we previously showed that plasma protein in fasted raptors increased after being refed in captivity $[15,16]$. Consequently, it is tempting to suggest that, in terms of absolute food intake, free-living chick eagles were fed better in Doñana than in Madrid. That hypothesis may be supported by the high uric acid levels, but low cholesterol values, which were found in the nestlings of Madrid compared to those in their counterparts of Doñana. These differences closely resemble those between undernourished and refed subadult eagles (Table 4) that we have discussed in the preceding section.

\section{Acknowledgements}

Funding was provided by CSIC and ICONA. We want to acknowledge the help of L. García, M. de la Riva, J.J. Negro, M.L. Chacón and R. Cadenas in the field work, and F. Recio in the blood analyses.

\section{References}

[1] Aguilera E, Moreno J, Ferrer M. Blood chemistry values in three Pygoscelis penguins. Comp Biochem Phys 1993;105A:471-3.
[2] Alonso JC, Huecas V, Alonso JA, Abelenda M, Muñoz-Pulido R, Puerta ML. Hematology and blood chemistry of adult white storks (Ciconia ciconia). Comp Biochem Phys 1991;98A:395-7.

[3] Balasch J, Musquera S, Palacios L, Jimenez M, Palomeque J. Comparative hematology of some falconiforms. Condor 1976;78:258-9.

[4] Bowes VA, Julian RJ, Stirtzinger T. Comparison of serum biochemical profiles of male Broilers with female Broilers and White Leghorn chickens. Can J Vet Res 1989;53:7-11.

[5] Bustamante J, Travaini A. Effect of keeping plasma frozen at $-20^{\circ} \mathrm{C}$ on the concentration of blood metabolites. Comp Biochem Phys 1994;107A:661-4.

[6] Casterline JL, Williams $\mathrm{CH}$. The effect of 28-day pesticide feeding on serum and tissue enzyme activities of rats fed diets of varying casein content. Toxicol Appl Pharmacol 1971;18:60718.

[7] Cooper JE, Needham JR, Fox NC. Bacteriological, haematological and clinical chemical studies on the Mauritius Kestrel (Falco punctatus). Avian Pathol 1986;15:349-56.

[8] Costa ND, McDonald DE, Swan RA. Age-related changes in plasma biochemical values of farmed emus (Dromaius novaehollandiae). Aust Vet J 1993;70:341-4.

[9] de le Court C, Aguilera E, Recio F. Plasma chemistry values of free-living white spoonbills (Platalea leucorodia). Comp Biochem Phys 1995;112A:137-41.

[10] Dieter MP. Plasma enzyme activities in Coturnix quail fed graded doses of DDE, polychlorinated biphenyl malathion and mercuric chloride. Toxicol Appl Pharmacol 1974;27:86-98.

[11] Fairbrother A, Craig MA, Walker K, O'Loughlin D. Changes in Mallard (Anas platyrhynchos) serum chemistry due to age, sex, and reproductive condition. J Wildlife Dis 1990;26:67-77.

[12] Ferrer M. Hematological studies in birds. Condor 1990;92:1085-6.

[13] Ferrer M. El Aguila Imperial. Madrid: Editorial Quercus, 1993.

[14] Ferrer M, de le Court C. Sex determination in the Spanish Imperial Eagle. J Field Ornithol 1992;63:359-64.

[15] Ferrer M, García-Rodríguez T, Carrillo JC, Castroviejo J. Hematocrit and blood chemistry values in captive raptors (Gyps fulvus, Buteo buteo, Milvus migrans, Aquila heliaca). Comp Biochem Phys 1987;87A:1123-7.

[16] García-Rodríguez T, Ferrer M, Carrillo JC, Castroviejo J. Metabolic responses of Buteo buteo to long-term fasting and refeeding. Comp Biochem Phys 1987;87A:381-6.

[17] García-Rodríguez T, Ferrer M, Carrillo JC, Castroviejo J. Circadian rhythms of determined blood chemistry values in Buzzards and Eagle Owls. Comp Biochem Phys 1987;88A:6639.

[18] Gee GF, Carpenter JW, Heusler GL. Species differences in hematological values of captive cranes, raptors and quail. $\mathbf{J}$ Wildlife Manage 1981;45:463-83.

[19] González JL, Hiraldo F. Some hematological data from Marsh Harriers (Circus aeruginosus) in central Spain. Comp Biochem Phys 1991;100A:735-7.

[20] González LM. Historia natural del águila imperial ibérica. Ph.D. diss. Madrid: Universidad Autónoma de Madrid, 1989.

[21] Gordon MS. Animal Physiology: Principles and Adaptations. Los Angeles CA: Macmillan, 1972.

[22] Halliwell WH. Serum chemistry profiles in the health and disease of birds of prey. In: Cooper JE, Greenwood AG, editors. Recent Advances in the Study of Raptor Diseases. West Yorkshire: Chiron Publications, 1981:111-112.

[23] Hernández LM, Rico MC, González MJ, Hernán MA, Fernández MA. Presence and time trends of organochlorine and heavy metals in eggs of predatory birds of Spain. J Field Ornithol 1986;57:270-82.

[24] Hoffman DJ, Franson JC, Pattee OH, Bunck CM, Murray HC. Biochemical and hematological effects of lead ingestion in nestling American kestrels (Falco sparverius). Comp Biochem Phys 1985;80C:431-9. 
[25] Jeffrey DA, Peakall DB, Miller DS, Herzberg GR. Blood chemistry changes in food-deprived herring gulls. Comp Biochem Phys 1985;81A:911-3.

[26] King W. Endangered Birds of the World. Gland: IUCN/ICBP, 1981.

[27] Kocan RM, Pitts SM. Blood values of canvasback duck by age, sex and season. J Wildlife Dis 1976;12:341-5.

[28] Lehninger AL. Principles of Biochemistry. New York: Worth Publishers, 1982.

[29] Levy A, Perelman B, Waner T, Grevenbroek M, Creveld C, Yagil R. Reference blood chemical values in ostriches (Struthio camelus). Am J Vet Res 1989;50:1548-50.

[30] Lewandowski AH, Campbell TW, Harrison GJ. Clinical chemistries. In: Harrison GJ, Harrison LR, editors. Clinical Avian Medicine and Surgery. Philadelphia, PA: Saunders, 1986:192-200.

[31] Lumeij JT. Relation of plasma calcium to total protein and albumin in African grey (Psittacus erithacus) and Amazon (Amazona spp.) parrots. Avian Pathol 1990;19:661-7.

[32] Lumeij JT, Remple JD. Plasma urea, creatinine and uric acid concentrations in relation to feeding in peregrine falcons (Falco peregrinus). Avian Pathol 1991;20:79-83.

[33] Lumeij JT, Remple JD, Riddle KE. Relationship of plasma total protein and albumin to total calcium in peregrine falcons (Falco peregrinus). Avian Pathol 1993;22:183-8.

[34] McDaniel LS, Chute HL. Enzyme activity in chicken plasma. Am J Vet Res 1961;22:88-103.

[35] Migliorini RH, Linder C, Moura JL, Veiga JAS. Gluconeogenesis in a carnivorous bird (black vulture). Am J Physiol 1973;225:1389-92

[36] Mori JG, George JC. Seasonal changes in serum levels of certain metabolites, uric acid and calcium in the migratory Canada Goose (Branta canadensis interior). Comp Biochem Phys 1978;59B:263-9.

[37] Mulley RC. Haematology and blood chemistry of the black duck (Anas superciliosa). J Wildlife Res 1979;15:437-41.

[38] Okumura J, Tasaki I. Effect of fasting, refeeding and dietary protein levels on uric acid and ammonia content of blood, liver and kidney in chickens. J Nutr 1969;97:316-20.

[39] Peinado VI, Polo FJ, Viscor G, Palomeque J. Hematology and blood chemistry values for several flamingo species. Avian Pathol 1992;21:55-64.

[40] Perry MC, Obrecht HH, Williams BK, Kuenzel WJ. Blood chemistry and hematocrit of captive and wild canvasbacks. J Wildlife Manage 1986;50:435-41.

[41] Pick R, Jain S, Katz LN, Johnson P. Effect of dietary protein level on regression of cholesterol-induced hypercholesterolemia and atherosclerosis of cockerels. J Atheroscler Res 1965;5:1625 .
[42] Polo FJ. Estudio Bioquímico y Enzimático del Plasma de Aves en Cautividad. Ph.D. diss. Barcelona: Universitat de Barcelona, 1995.

[43] Polo FJ, Celdrán JF, Peinado VI, Viscor G, Palomeque J. Hematological values for four species of birds of prey. Condor 1992;94:1007-13.

[44] Polo FJ, Celdrán J, Viscor G, Palomeque J. Blood chemistry of captive herons, egrets, spoonbill, ibis and gallinule. Comp Biochem Phys 1994;107A:343-7.

[45] Puerta ML, Alonso JC, Huecas V, Alonso JA, Abelenda M, Munoz-Pulido R. Hematology and blood chemistry of wintering Common Cranes. Condor 1990;92:210-4.

[46] Puerta ML, García del Campo AL, Abelenda M, Fernandez A, Huecas V, Nava MP. Hematological trends in flamingos, Phoenicopterus ruber. Comp Biochem Phys 1992;102A:683-6.

[47] Puerta ML, Huecas V, García del Campo AL. Hematology and blood chemistry of the Chilean Flamingo. Comp Biochem Phys 1989;94A:623-5.

[48] Puerta ML, Muñoz Pulido R, Huecas V, Abelenda M. Hematology and blood chemistry of chicks of White and Black Storks (Ciconia ciconia and Ciconia nigra). Comp Biochem Phys 1989;94A:201-4.

[49] Redig P. Medical Management of Birds of Prey. St. Paul MN: The Raptor Center, College of Veterinary Medicine, University of Minnesota, 1991.

[50] Rehder NB, Bird DM. Annual profile of blood packed cell volumes of captive American kestrels. Can J Zool 1983;61:2550-5.

[51] Rehder NB, Bird DM, Lagüe PC. Variation in in blood packed cell volumen of captive American kestrels. Comp Biochem Physiol 72A:105-109.

[52] Rehder NB, Bird DM, Lagüe PC, Mackay C. Variation in selected hematological parameters of captive Red-tailed hawks. J Wild Dis 18:105-109.

[53] Smith EE, Bush M. Haematological parameters on various species of strigiformes and falconiformes. J Wildlife Dis 1978;14:447-50.

[54] Tell LA, Citino SD. Hematologic and serum chemistry reference intervals for cuban Amazon parrots (Amazona leucocephala leucocephala). J Zoo Wildlife Med 1992;23:62-4.

[55] Viñuela J, Ferrer M, Recio F. Age-related variations in plasma levels of alkaline phosphatase, calcium and inorganic phosphorus in chicks of two species of raptors. Comp Biochem Phys 1991;99A:49-54.

[56] Walt BK, Merril AL. Composition of foods. US Dept Agric Res Serv Agric Handbook 1975;8.

[57] Yeh S-JC, Leveille GA. Cholesterol and fatty acid synthesis in chicks fed different levels of protein. J Nutr 1972;102:349-58. 